\title{
SUSTAINABLE BUSINESS DEVELOPMENT THROUGH CSR IMPLEMENTATION AT PT. HEINZ ABC INDONESIA
}

\author{
Mundakir Mundakir \\ The London School of Public Relations \\ mudzakir.winata@gmail.com
}

\begin{abstract}
A good business is a growing business. The development of business is determined by good relationships with parties concerned, which is customers, markets, and relationships those forces combine to create opportunities for growth. Business development also concern about creating opportunities for that value to persist over the long term and sustain. In other hand, as business organization, company have responsibility to contribute to society where they operate, or called as corporate social responsibility (CSR). One of the aim from CSR activity is to gain sustainability development both for society and company. PT. Heinz ABC Indonesia as a corporation member of Global Kraft Heinz Company which operated in Indonesia have responsible to the community and environment. PT. Heinz ABC Indonesia, as one of the multinational food producers committed to be able to implement the CSR activities with activities related to the fulfillment of food needs in the vicinity. It is embodied in the value of companies committed to becoming "to be best food company, growing better world". The research will focus on sustainable business development through CSR Implementation at PT. Heinz ABC Indonesia. Through CSR implementation, PT. Heinz ABC Indonesia aim to develop the business by focus on environmental and social interrelationships with initiatives to reduce the amount of waste or emissions, resulting in lower costs. Also, developing the business using future benefit from social responsibility will keep in good company and brand image as well.
\end{abstract}

Keywords: Sustainable business development, Corporate Social Responsibility.

\section{INTRODUCTION}

The good brand of the company are the most valuable assets for company. Because this is very influential on business sustainability. Increasingly existing and surviving a company brand indicates that the company has a good name in the community. Because the community believes in the company or brand, so they continue to use it. Large companies operating nationally even internationally and having products known in the world cannot be separated from the good name that is always guarded. Their good name is obtained by providing the best quality and excellent service so that customers and users are satisfied. Sustainability of business is largely determined by develop the business in the interactions of an organization from customers, markets, and relationships those forces combine to create opportunities for growth.

According to Wiener (2003), business development entails task and processes to develop and implement growth opportunities within and between organizations. Business development also can concernabout creating opportunities for that value to persist over the long-term, to keep the floodgates open so that value can flow indefinitely and sustain. Sustainable business development has several focuses which determine the essence of this term, not only economic aspect but also on social and environmental dimensions. These termincludes social, economic and environmental dimensions, which should be integrated in order to achieve the goals and should be balanced as interdependent pillars of sustainable development. Focus on cooperation,sustainable development requires the active participation of all major groups includes organizations, local authorities, business and industry as well as other stakeholders, including local communities, volunteer groups and foundations (United Nations General Assembly, 2012, p.8).

PT. Heinz ABC Indonesia as member of Global Kraft Heinz Company which operated in Indonesia have responsible to community and environment. PT. Heinz ABC Indonesia, as one of the 
multinational food producers committed to be able to implement the CSR activities with activities related to the fulfillment of food needs in the vicinity. It is embodied in the value of companies committed to becoming "to be best food company, growing better world". CSR activities of a company are also regulated in Law No. 40 Year 2007, that required to support government policies related to those activities. Through this law, the industry or corporation is obliged to implement it, but this obligation is not a burdensome burden and plays a role in realizing social welfare and managing the quality of life. PT. Heinz ABC Indonesia through CSR implementation expected to future financial return by increasing stakeholder's satisfaction as impact of maintaining best quality product through maximizing employee productivity meet global quality requirement.Sustainable growth of company strongly depends on stakeholder's satisfaction (Fonseca et al, 2011).

\section{METHOD}

This paper is a qualitative research by combining several steps in collecting data and information, and analysing to generate results and conclusion. Instruments used to collect the data such as interview with key person at internal PT. Heinz ABC Indonesia using guidelines that have been systematically arranged and complete for data collection. official website Kraft Heinz Company (www.kraftheinzcompany.com) and internal company communication and information that allowed to share to public.

In this research, will using case study at PT. Heinz ABC Indonesia. Focus on this research are exploring two elements which is corporate social responsibility consist of sub elements such as customer, employee, society and government and element business development consist of market, customer and employee. Historical from PT. Heinz ABC Indonesia as member of Global Kraft Heinz Company will be explored prior describe CSR implementation at those company. By knowing the company history is expected to provide a more in-depth description of the company and the values of the company as a guide, making it easier to understand the company's activities related to the implementation of CSR in the country where the company operates.

\section{RESULT AND DISCUSSION}

PT Heinz ABC Indonesia was originally named CV. Central Food Industry Corporation was founded by Chu Sok Sam in 1975 as a producer of soy sauce produced by soybean processing. In 1978 the company expanded its business with the production of chili sauce and tomato sauce the following year. With a growing business, in 1982 owner of the company decided to change the form of his business from CV to PT, and finally a new company named PT. Aneka Bina Cipta Central Food Industry abbreviated as PT. ABC Central Food. During the journey, PT. ABC Central Food has expanded the business by export to other country in Asia, Europe and America. In 1999 HJ. Heinz, who has a similar business with $\mathrm{ABC}$ Central Food was interested in buying the company share, and bought the company with $80 \%$ share and reforming company become PT. Heinz ABC Indonesia. In 2015 a global corporation Kraft Food Group merge with HJ. Heinz to became the new company which Kraft Heinz Co. as the $5^{\text {th }}$ largest food and beverage company in world. From the merger of two large companies, PT. Heinz ABC Indonesia is a subsidiary of Kraft Heinz Company.

During the operation in Indonesia, PT. Heinz ABC Indonesia has three plant manufacture which site Daan Mogot Jakarta, site Karawang West Java and site Pasuruan East Java. Regarding to the Law No. 40 Year 2007, that required the corporation which operated in Indonesia to support government policies related to social responsibility and plays a role in realizing social welfare and managing the quality of life. And this is in line with the value of companies committed to becoming "to be best food company, growing better world". As an embodiment of those two kind of regulation, according to Achmad, Senior HR Manager (2018), PT. Heinz ABC Indonesia create four main program CSR which related to seasonal and conditional event, related to operation of company, related to community development and the biggest event is involved all company member engage with global company CSR activity.

CSR implementation related to operational of company, PT. Heinz ABC Indonesia has done the activity related to production waste disposal. According to Achmad HR Senior manager at PT. Heinz $\mathrm{ABC}$ Indonesia, all of three plant that Heinz $\mathrm{ABC}$ Indonesia includes Daan Mogot Karawang and 
Pasuruan site have is not in an industrial area but is neighboring to the residents and in the vicinity of settlement. They should ensure the waste treatment before being released from the factory must comply with provisions of government in this case the environment ministry and all the waste is environmentally friendly. Achmad state: "We have a clean river program, namely Mookevart (river in Daan Mogot) and irrigation channels. So, we helped the local community to clean up the river from pollutant and so on. Because behind our factory we have residential housing and there is irrigation, and we use the irrigation channels to discharge our liquid waste. Daan Mogot through Mookevart, Pasuruan through irrigation channel and Pasuruan through Citarum river. But we have processed it, in accordance with government regulations. The AMDAL is appropriate, if there is no treated to pollutant that pollution will occur and violates the law."

CSR implementation related to the community development, PT. Heinz ABC Indonesia has done with activity to some community surround the plant. Each plant work together with Posyandu every month to provide healthy food, such as mung bean and juice. And PT. Heinz ABC Indonesia together with Posyandu administrators to find out what community need, such as health education for toddlers and pregnant women, they provide services that are experts in the field. Another CSR implementation that already done is planting trees. PT. Heinz ABC Indonesia together with local community to find out kind of trees they need, how high they are, and where they want to plant, including follow up in term of the maintenance the trees. CSR Implementation related to seasonal and conditional event, PT. Heinz $\mathrm{ABC}$ Indonesia already done with some activity such as event Eid al-Adha, Heinz ABC Indonesia always give goats and participated in the deduction and process of giving to the poor. During Ramadhan, Heinz ABC Indonesia always cooperates with Islamic boarding school in providing compensation for students and ' t ' their teaching staff. activity when in an area, $\mathrm{ABC}$ is always the latest earthquake in
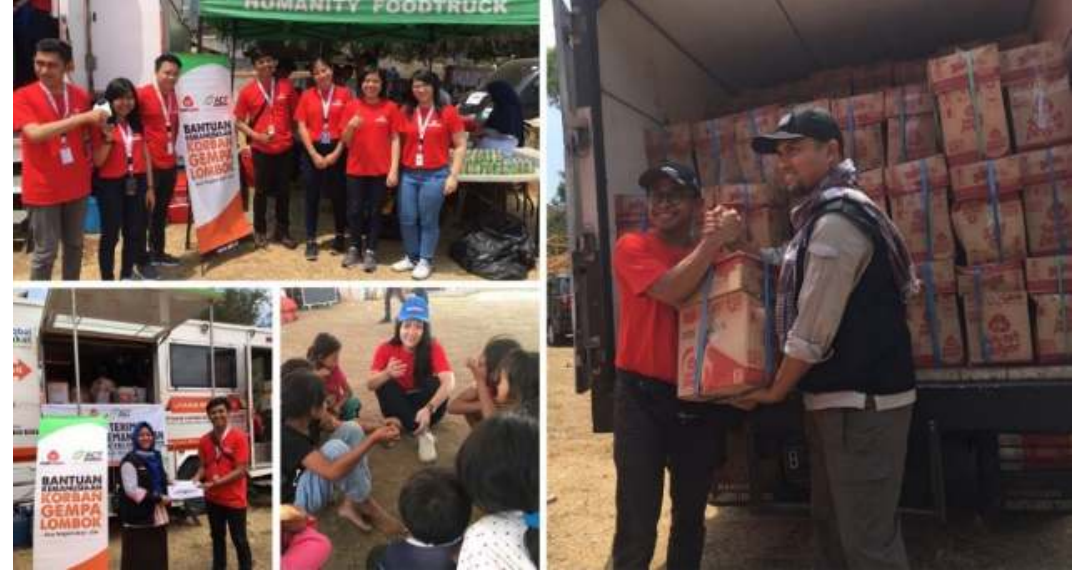

Another calamity Heinz Indonesia involved,

Lombok.

Figure 1. Heinz ABC Indonesia done charity for earthquake in Lombok

The biggest CSR implementation in PT. Heinz ABC Indonesia that involved all company member engage with Kraft Heinz global activity is Stop Hunger event. Stop Hunger program is an annual activity that done by packing food ready to cook and deliver to all areas in need. In 2017 Heinz $\mathrm{ABC}$ Indonesia done to packing 150.000 pack of food. This event already did since 2015 with theme "rise against hunger". Purpose of this event is an embodiment of global Kraft Heinz company value which want to growing a better world.

All those CSR activities that done by PT. Heinz ABC Indonesia involved all main stakeholder which is investor as fund entity, employee who's in charge in technical event, government who's have regulation that all corporate organization should comply and obligate to social responsibility, 
and the customer as part of society as main element to do the activity. A stakeholder is any person or group of people that are having an ownership right or any form of interest or claim on an organization (Clarkson, 1995). Stakeholders can be defined as any group or individual that can affect or be affected by the process of achieving business objectives (Freeman, 1984). Stakeholder theory focuses on the relationship between the business organization and any single individual or group of people or functional bodies that are involved in the process of achieving organizational objectives, such as investors, employees, customers, society and government. Corporations should contribute towards societal development, improve on corporate reputation and be a corporate citizenry through CSR implementation. The social responsibility of business consists of economic, legal ethical and discretionary initiatives aimed at fulfilling stakeholder expectations. Corporate social responsibility implementation based on five dimensions; environmental; social, economic, stakeholder and charity dimension (Dahlsrud, 2008).
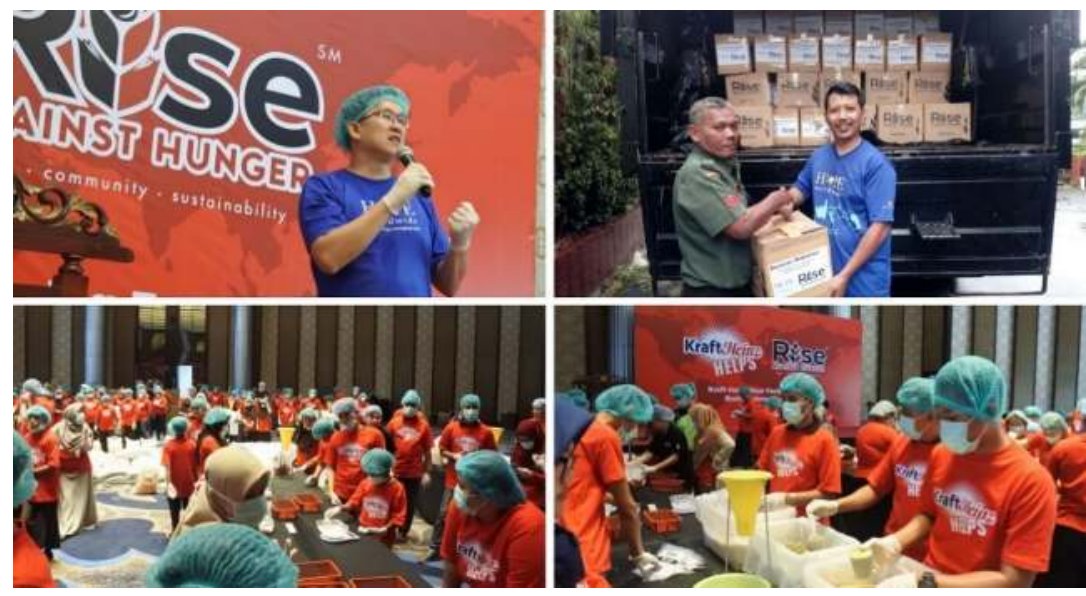

Figure 2. Heinz ABC Indonesia done program stop hunger in 2017.

Business development is the creation of long-term value for an organization from customers, markets, and relationships (Wiener, 2003). Sustainable business development has several focuses which determine the essence of this term, not only economic aspect but also on social and environmental dimensions. United Nations define sustainable development includes social, economic and environmental dimensions, which should be integrated in order to achieve the goals and should be balanced as interdependent pillars of sustainable development (United Nations General Assembly, 2002 in Behringer, 2016). Sustainable development through CSR has gained in the circle of corporations, the reason of which among others might be that the long term goals for the future are much more acceptable for the business sphere than the responsibility conception requiring immediate action.

By implementing CSR will bring numerous positive impact as part of sustainable development. Multitude of improvements, starting with the increase in revenues to encourage both large and small enterprises to spread the idea of CSR and put it into practice in their daily operations. Kurucz, et.al. (2008) profess a key significance of corporate social responsibility for building a brand image. Direct benefit to the company from CSR implementation are ease access to labour and security guarantees at work. ThroughCSR implementation expected to future financial return by increasing customer satisfaction as impact of maintaining best quality product through maximizing employee productivity. Achmad (2018) state:"At the Karawang site there are frequent labor demonstrations every year. Well, the mass demonstration combed all the factories and sweeping employees to participate in demonstrations and force the production to stop. Because of our CSR activities and have an impact on good relations with the local people, it is precisely the residents who guard the gates of our company, preventing and driving out the masses to conduct sweeping, so that our production activities can continue and their conduciveness is maintained. We also need conditional season workforce every year, we might need 200 workers and it must be available within one week. And that can easily be realized, so that the energy needs can be pursued with a tight time." 
Porter and Kramer (2006) describes the determinants of gaining advantage against competitors within CSR implementation such us creating a positive image of a company. The business can influence the customers and other members of communities by maintaining a responsible representation. Another benefit from CSR implementation is shaping proper relations with all the stakeholders, a company shows that stakeholders' needs are important to it, for example by increasing transparency in relation to contracts, but also to environmental actions and to respecting human rights. CSR implementation also increasing morale of employees, CSR inspires employee loyalty and motivates to more efficient work.

Leonard (2018), HR Manager site Daan Mogot state: “The citizens strongly defend ABC products. Because people feel very helped by the ABC Heinz company. The market condition is now that the competition is very tight, now CSR is actually part of marketing activities as well because it builds the image of $A B C$ products through direct touch to consumers, and consumers are citizens."

\section{CONCLUSION}

CSR implementation is very beneficial for both companies and communities. Corporations can obtain financial benefits indirectly through the creation of good reputation, thereby strengthening the position of company in market. CSR can be part of marketing activities as well because it builds the image of Heinz ABC products through direct touch to consumers, and consumers are citizens, as well as CSR activities have an impact on good relations with the local society, it is creating conducive work environment that are side by side with the community. Those benefits are impact of increasing stakeholder's satisfaction, include on this stakeholder member is employees, investors, customers and government. The society people feel very helped by CSR implementation from Heinz ABC Indonesia. For society, there are some benefit from CSR implementation. Benefit of CSR implementation for society which can be felt directly and in the short term through assistance from companies, and long term benefits through improving the quality of education, infrastructure and health for better life.

\section{REFERENCES}

Behringer, K., \& Szegedi K. (2016). The role of CSR in achieving sustainable development-theoretical $\begin{array}{llll}\text { approach. } & \text { European } & \text { Scientific Journal, } & \text { 12(22). }\end{array}$ https://eujournal.org/index.php/esj/article/viewFile/7936/7660.

Clarkson, M.B. (1995). A stakeholder framework for analyzing and evaluating corporate social performance, Academy of Management Review, 20 (1), 92-117. https://www.jstor.org/stable/pdf/258888.pdf?refreqid=excelsior\%3A284326cafb64e18b8cde3a $\underline{756757 \mathrm{e} 4 \mathrm{e} 4}$.

Dahlsrud, A. (2008). How Corporate Social Responsibility is defined: an Analysis of 37 Definitions, Corporate Social Responsibility and Environmental Management, 15.113.https://onlinelibrary.wiley.com/doi/epdf/10.1002/csr.132.

Fonseca, L., Amilcar, R., Alvaro, R., Cristina, B.A., \& Paulo, S., (2011). Stakeholder satisfaction and sustainable success. $\quad$ Business $\quad$ Sustainability $\quad$ II. http://citeseerx.ist.psu.edu/viewdoc/download?doi=10.1.1.823.9455\&rep=rep1\&type=pdf.

Freeman, R.E. (1984). Strategic management: A stakeholder approach, Pitman, Boston. https://www.researchgate.net/profile/John_Mcvea/publication/228320877_A_Stakeholder_App roach to Strategic Management/links/5abcb11d45851584fa6e1ff7/A-Stakeholder-Approachto-Strategic-Management.pdf?origin=publication detail.

Kurucz, E.C., Colbert, B.A., \& Wheeler D. (2008). The Business Case for Corporate Social Responsibility. The Oxford Handbook of Corporate Social Responsibility, Oxford University Press Inc., New York, $(83$ - 112).https://www.researchgate.net/publication/235771847. 
United Nations General Assembly. (2012). The future we want.http://www.un.org/en/development/desa/population/migration/generalassembly/docs/glob alcompact/A RES 66 288.pdf.

Wiener, O., Bird, T., Cassel, J., Doolan, K., Hoskins, T., Klyhn, D., \& Marsden, H. (2003). Business development Practice. Churchill College University of Cambridge. Moller PSF Group.https://www.mollercentre.co.uk/wp-content/uploads/2016/04/Business-Development.pdf 